\title{
Effects of replacing different proportions of barley grain by barley fibre on performance of dairy bulls
}

\author{
Arto Huuskonen \\ MTT Agrifood Research Finland, Animal Production Research, FI-92400 Ruukki, Finland, \\ email:arto.huuskonen@mtt.fi \\ Hannele Khalili \\ MTT Agrifood Research Finland, Animal Production Research, FI-31600 Jokioinen, Finland \\ Erkki Joki-Tokola \\ MTT Agrifood Research Finland, Animal Production Research, FI-92400 Ruukki, Finland
}

\begin{abstract}
The objective of the present experiment was to study the effects of partial replacement of barley grain with barley fibre (BF) on animal performance, carcass traits and diet digestibility of growing dairy bulls. The feeding experiment comprised 20 Finnish Ayrshire bulls and 12 Holstein-Friesian bulls, and four treatments ( 8 bulls per treatment). There were four diets with two offered at stage 1 (from the initiation of the study to $450 \mathrm{~kg}$ live weight) and four at stage 2 (from $450 \mathrm{~kg}$ live weight to slaughter). The control diet (BF0) included grass silage ( $460 \mathrm{~g} \mathrm{~kg}^{-1}$ dry matter) and barley grain (540), BF25 diet included grass silage (460), barley grain (405) and BF (135), BF50 diet included grass silage (460), barley grain (270) and BF (270), and BF75 diet included grass silage (460), barley grain (135) and BF (405). At stage 1 there were only two treatments (BF0 and BF50) and at stage 2, all four treatments were included. All bulls were fed total mixed ration ad libitum. The mean initial live weight of the bulls was $261 \mathrm{~kg}$ and the mean final live weight 650 $\mathrm{kg}$. At stage 1 there were no significant treatment differences in dry matter, energy or protein intakes or in live weight gain. At stage 2, replacing barley grain with BF led to a linear decrease of daily live weight gain $(\mathrm{P}<0.05)$ and a linearly reduced feed conversion $\left(\mathrm{kg}\right.$ dry matter $\mathrm{kg}^{-1}$ live weight gain $)(\mathrm{P}<0.05)$. The apparent digestibility of the organic matter and neutral detergent fibre decreased linearly with increasing $\mathrm{BF}$ supplementation $(\mathrm{P}<0.001)$. The dressing proportion and the carcass fat score decreased linearly $(\mathrm{P}<$ 0.05 ) with partial replacement of barley grain with BF. On carcass conformation, treatment had a significant $(\mathrm{P}<0.05)$ quadratic effect: the BF25 and BF50 diets were classified highest. The results indicate that 50\% of barley starch can be replaced with BF without affecting growth, but feed efficiency factors may decrease when barley starch is replaced with BF. At $75 \%$ replacement, feed intake was reduced, which resulted in a lower energy intake and reduced level of performance.
\end{abstract}

Key-words: Beef production, dairy-breed bulls, total mixed ration, barley fibre, by-products

(C) Agricultural and Food Science

Manuscript received June 2007 
Vol. 16 (2007): 232-244

\section{Introduction}

With increasing oil prices over recent years interest in bio-ethanol production has increased. In Finland, the current integrated production of ethanol and starch creates also barley fibre (BF) as a by-product. Barley fibre is a fibrous product comprised mainly of the cell wall fraction of barley endosperm and is used as energy source in cattle feeding. A detailed description of the integrated starch-ethanol process and the products of the process are given by Näsi (1988). As the integrated starch-ethanol process can be used also for the production of bio-ethanol, it is evident that increasing quantities of by-products will be produced in the future. By-products, such as BF, tend to be low-priced feeds. Therefore, it is important to determine the potential of $\mathrm{BF}$ to replace grain in the rations of growing and finishing bulls.

The use of total mixed ration (TMR) in beef production systems is receiving considerable attention in Finland. Total mixed ration feeding and the European Union policy reducing the price of grain in relation to forages have increased the proportion of concentrate in the diet of growing bulls. With increasing concentrate proportion the interest in substituting the starch-rich grain by more fibrous ingredients like BF has increased. In addition, the fact that today BF is $15-20 \%$ cheaper than barley grain has increased the interest of beef producers to use BF.

According to Root and Huhtanen (1998), with separate feeding (concentrate proportion $390 \mathrm{~g} \mathrm{~kg}^{-1}$ dry matter (DM)) including BF in the diet of growing bulls (initial live weight (LW) $205 \mathrm{~kg}$ and final LW $500 \mathrm{~kg}$ ) did not affect feed or energy intake markedly. The average live weight gain (LWG) or carcass characteristics were not significantly different for the different BF replacements, but towards the end of the experiment (LW $350-500 \mathrm{~kg}$ ) the LWG of the bulls fed BF tended to decrease compared to barley grain (Root and Huhtanen 1998). With TMR feeding (concentrate proportion $570 \mathrm{~g}$ $\mathrm{kg}^{-1} \mathrm{DM}$ ), the LWG of the dairy bulls (initial LW $280 \mathrm{~kg}$ and final LW $675 \mathrm{~kg}$ ) given BF tended to be higher than that of bulls given barley grain diets up to $500 \mathrm{~kg} \mathrm{LW}$ when replacing half of the bar- ley grain with BF (Huuskonen unpublished data). However, inclusion of BF in the diet decreased the daily gain from $500 \mathrm{~kg} \mathrm{LW}$ to slaughter. There were no significant treatment effects on carcass characteristics (Huuskonen unpublished data). According to these preliminary findings, the bulls performed well when $50 \%$ of the barley grain concentrate was replaced with $\mathrm{BF}$ in the early part of the growing period (Root and Huhtanen 1998: 205 to 350 kg LW, Huuskonen unpublished data: 280 to 500 $\mathrm{kg} \mathrm{LW}$ ), but the situation during the final finishing period is still unclear. Therefore, the objective of the present experiment was to study the effects of partial replacement of barley grain with $\mathrm{BF}$ on animal performance, carcass traits and diet digestibility of growing dairy bulls.

\section{Materials and methods}

\section{Animals and experimental design}

The feeding experiment, started in September 2005 and ended in August 2006, was conducted in the experimental barn of North Ostrobothnia Research Station of MTT Agrifood Research Finland (Ruukki, $\left.64^{\circ} 44^{\prime} \mathrm{N}, 25^{\circ} 15^{\prime} \mathrm{E}\right)$. The experimental procedures were evaluated and approved by the Animal Care and Use Committee of MTT Agrifood Research Finland. Twenty Finnish Ayrshire bulls and twelve Holstein-Friesian bulls were used in the experiment. All animals were purchased from local dairy farms. Before the feeding experiment they received grass silage and concentrates (commercial pelleted calf starter, barley and rapeseed meal). At the beginning of the present experiment the animals (initial LW $261 \pm 34.0 \mathrm{~kg}$ and age $195 \pm 5.2$ days, on average) were divided into four blocks of 8 animals by LW and breed. Age was not taken into account in the blocking, because of the small variations in age. Two randomly selected animals in each block were assigned to each treatment. The animals were housed in a tie-up barn and individually fed three times per day (at 8:00 a.m., 12:00 a.m., and 6:00 p.m.). Refused feed was collected and measured at 7:00 a.m. daily. 
Huuskonen, A. et al. Effects of replacing different proportions of barley grain by barley fibre

The bulls had free access to water from an open water bowl during the experiment.

All the bulls were fed TMR ad libitum (proportionate refusals 5\%) and the experiment included four treatments and two stages (Table 1):

(1) control (BF0): grass silage (460 $\left.\mathrm{g} \mathrm{kg}^{-1} \mathrm{DM}\right)$ and flattened barley grain (540)

(2) BF25: grass silage (460), flattened barley grain (405) and BF (135)

(3) BF50: grass silage (460), flattened barley grain (270) and BF (270)

(4) BF75: grass silage (460), flattened barley grain (135) and BF (405)

Stage 1 - from the initiation of the study to $450 \mathrm{~kg} \mathrm{LW}$. There were only two treatments (control and BF50).

Stage 2 - from $450 \mathrm{~kg} \mathrm{LW}$ to slaughter. All four treatments were included. The animals were moved to stage 2 on a treatment mean basis.

The commercial BF (produced by Altia Ltd, Koskenkorva, Finland) used in the experiment included BF (950 $\left.\mathrm{g} \mathrm{kg}^{-1} \mathrm{DM}\right)$, wet distillers' solubles (25) and molasses (25). The grass silage was direct-cut first-growth from a timothy (Phleum pratense) and meadow fescue (Festuca pratensis) sward and ensiled in bunker silos with a formic acid-based additive applied at a rate of $5 \mathrm{~L}$ per tonne of fresh grass. The animals received also a mineral supplementation

Table 1. Treatments and total mixed rations $\left(\mathrm{g} \mathrm{kg}^{-1} \mathrm{DM}\right)$ used in the feeding experiment in two experimental periods (stage $1=$ up to $450 \mathrm{~kg}$ live weight, stage $2=450$ $\mathrm{kg}$ live weight to slaughter).

\begin{tabular}{llrrrr}
\hline & & \multicolumn{3}{c}{ Treatment } \\
\cline { 3 - 6 } & & BF0 & BF25 & BF50 & BF75 \\
\hline Stage 1 & Silage & 460 & 460 & 460 & 460 \\
& Barley grain & 540 & 270 & 270 & 270 \\
& Barley fibre ${ }^{\text {a }}$ & 0 & 270 & 270 & 270 \\
Stage 2 & Silage & 460 & 460 & 460 & 460 \\
& Barley grain & 540 & 405 & 270 & 135 \\
& Barley fibre & 0 & 135 & 270 & 405 \\
\hline
\end{tabular}

${ }^{a}$ Commercial barley fibre (produced by Altia Ltd,

Koskenkorva, Finland) included ( $\left.\mathrm{g} \mathrm{kg}^{-1} \mathrm{DM}\right)$ barley fibre (950), wet distillers' solubles (25) and molasses (25).
( $150 \mathrm{~g}$ per head per day) and vitamin supplement (50 $\mathrm{g}$ per head per week). No animals were medicated on any of the treatments.

\section{Measurements}

The animals were weighed on two consecutive days at the beginning of the experiment. After that the animals were weighed every 28 days and before slaughter on two consecutive days. The target carcass weight in the experiment was $350 \mathrm{~kg}$, and the bulls were selected for slaughter based on LW and an assumed dressing proportion. The LWG was calculated as the difference between the means of initial and final weights. The estimated rate of carcass gain was calculated by assuming an initial carcass weight of 0.50 of initial LW which was used also in a previous study by Root and Huhtanen (1998). Dressing proportions were calculated from the ratio of hot carcass weight to final LW. For conformation, the development of carcass profiles, in particular the essential parts (round, back, shoulder), was taken into consideration according to the EUROP classification (E: excellent, U: very good, R: good, O: fair, $\mathrm{P}$ : poor), and for fat cover degree the amount of fat on the outside of the carcass and in the thoracic cavity was taken into account using a classification range from 1 to 5 (1: low, 2: slight, 3: average, 4: high, 5: very high). Each level of the conformation scale was subdivided into 3 sub-classes (i.e. $\mathrm{O}+, \mathrm{O}$ and $\mathrm{O}-$ ) to a transformed scale ranging from 1 to 15 , with 15 as the best conformation (Commission of the European Communities 1982).

\section{Diet and sample analyses}

Silage samples were analysed for DM (determined at $105^{\circ} \mathrm{C}$ for $20 \mathrm{~h}$ ) at the beginning of the experiment and twice a week thereafter for preparation of TMR. Silage sub-samples for chemical analyses were taken twice a week, pooled over periods of four weeks and stored at $-20^{\circ} \mathrm{C}$. Thawed samples were analysed for $\mathrm{DM}$, ash, crude protein $(\mathrm{CP})$, ether extract, neutral 
Vol. 16 (2007): 232-244

detergent fibre (NDF), starch, silage fermentation quality $(\mathrm{pH}$, water-soluble carbohydrates, lactic and formic acids, volatile fatty acids, soluble and ammonia $\mathrm{N}$ content of $\mathrm{N}$ ) and digestible organic matter $(\mathrm{OM})$ in DM (D value). Concentrate sub-samples were collected weekly, pooled over periods of eight weeks and analysed for DM, ash, CP, ether extract, NDF and starch. The analyses of DM, ash, CP and NDF were made as described by Ahvenjärvi et al. (2000). Starch was analysed according to McCleary et al. (1994). The ether extracts were determined according to procedure 920.39 of AOAC (1990) after acid (HCL) hydrolysis. Silages were analysed for fermentation quality by the methods described by Moisio and Heikonen (1989) and for digestible organic matter in DM by the method described by Nousiainen et al. (2003).

Diet digestibility was determined for all animals at stage 2, when the bulls were initially 512 $\mathrm{kg}$ LW. Feed and faecal samples were collected twice a day (at 7:00 a.m. and 3:00 p.m.) during the collection period ( $5 \mathrm{~d})$, pooled and stored frozen prior to analyses. The samples were analysed for DM, ash, CP and NDF as described above. Diet digestibility was determined using acid-insoluble ash as an internal marker (Van Keulen and Young 1977).

The metabolizable energy (ME) value of the silage was calculated as $0.16 \times \mathrm{D}$ value $(\mathrm{MAFF}$ 1981). The ME values of the concentrates were calculated as described by Schiemann et al. (1972) and MAFF (1984). The digestibility coefficients of concentrates were taken from Finnish feed tables (MTT 2006). The supply of amino acids absorbed from the small intestine (AAT) was calculated according to Finnish feed tables (MTT 2006).

\section{Statistical analysis}

The experiment was set up according to a randomized block design where animal was used as an experimental unit. The results are shown as least squares means, because the records of the one excluded animal were not replaced. The data were subjected to analysis of variance by using the SAS mixed model procedure (SAS 1999). The model used was

$$
\mathrm{y}_{\mathrm{ijk}}=\mu+\mathrm{B}_{\mathrm{j}}+\mathrm{E}_{\mathrm{i}}+\mathrm{e}_{\mathrm{ijk}},
$$

where $\mu$ is the overall mean, $B_{j}$ is blocking effect $(j=1, \ldots, 4)$ and $e_{i j k}$ is the random error term. $E_{i}$ is the effect of BF inclusion. Each block includes two animals $(\mathrm{k}=1,2)$ with the same BF inclusion. The effect of the BF inclusion was further divided into linear and quadratic effects using orthogonal polynomial contrasts.

\section{Results}

\section{Diet}

The chemical compositions and calculated contents of ME and AAT of the different feeds are given in Table 2. The grass silage was of good nutritional quality (i.e. D value $693 \mathrm{~g} \mathrm{~kg}^{-1} \mathrm{DM}$ and AAT content $\left.87 \mathrm{~g} \mathrm{~kg}^{-1} \mathrm{DM}\right)$. The preservation quality of the silage as indicated by $\mathrm{pH}$ values and contents of ammonia-N and fatty acids was good (Table 2). The calculated energy value of barley grain was $14 \%$ higher than that of $\mathrm{BF}$, but $\mathrm{BF}$ contained slightly more CP (139 vs. $131 \mathrm{~g} \mathrm{~kg}^{-1} \mathrm{DM}$ ) than barley grain. However, barley grain contained $10 \%$ more AAT compared with BF. The starch content of BF was clearly lower (71 vs. $535 \mathrm{~g} \mathrm{~kg}^{-1} \mathrm{DM}$ ) and the NDF content higher (601 vs. $220 \mathrm{~g} \mathrm{~kg}^{-1} \mathrm{DM}$ ) compared with barley grain. The average chemical compositions of the TMRs used are presented in Table 3. Replacing barley grain with BF increased the NDF and decreased the starch and energy contents in the diets.

\section{Feed intake and animal performance}

One animal (in the BF75 diet) was excluded from the study due to several occurrences of bloat. There was no reason to suppose that the diet had caused this problem. At stage 1 (bulls up to $450 \mathrm{~kg} \mathrm{LW}$ ), 


\section{AGRICULTURAL AND FOOD SCIENCE}

Huuskonen, A. et al. Effects of replacing different proportions of barley grain by barley fibre

Table 2. Chemical composition and feeding values of concentrates and grass silage.

\begin{tabular}{|c|c|c|c|}
\hline & Silage & Barley & Barley fibre \\
\hline Number of samples & 11 & 5 & 5 \\
\hline Dry matter (DM), $\mathrm{g} \mathrm{kg}^{-1}$ feed & 285 & 887 & 921 \\
\hline Organic matter $(\mathrm{OM}), \mathrm{g} \mathrm{kg}^{-1} \mathrm{DM}$ & 914 & 977 & 963 \\
\hline Crude protein, $\mathrm{g} \mathrm{kg}^{-1} \mathrm{DM}$ & 170 & 131 & 139 \\
\hline Neutral detergent fibre, $\mathrm{g} \mathrm{kg}^{-1} \mathrm{DM}$ & 548 & 220 & 601 \\
\hline Starch, $\mathrm{g} \mathrm{kg}^{-1} \mathrm{DM}$ & $\mathrm{ND}^{\mathrm{a}}$ & 535 & 71 \\
\hline Ether extract, $\mathrm{g} \mathrm{kg}^{-1} \mathrm{DM}$ & 35 & 22 & 65 \\
\hline Digestible $\mathrm{OM}$ in DM, $\mathrm{g} \mathrm{kg}^{-1} \mathrm{DM}$ & 693 & ND & ND \\
\hline Metabolizable energy, $\mathrm{MJ} \mathrm{kg}^{-1} \mathrm{DM}$ & 11.1 & 13.2 & 11.6 \\
\hline $\mathrm{AAT}^{\mathrm{b}}, \mathrm{g} \mathrm{kg}^{-1} \mathrm{DM}$ & 87 & 106 & 96 \\
\hline \multicolumn{4}{|l|}{ Fermentation quality of silage } \\
\hline $\mathrm{pH}$ & 4.3 & & \\
\hline Volatile fatty acids, $\mathrm{g} \mathrm{kg}^{-1} \mathrm{DM}$ & 16 & & \\
\hline Lactic + formic acid, $\mathrm{g} \mathrm{kg}^{-1} \mathrm{DM}$ & 42 & & \\
\hline Water soluble carbohydrates, $\mathrm{g} \mathrm{kg}^{-1} \mathrm{DM}$ & 60 & & \\
\hline \multicolumn{4}{|l|}{ In total nitrogen, $\mathrm{g} \mathrm{kg}^{-1}$} \\
\hline Ammonia $\mathrm{N}$ & 75 & & \\
\hline Soluble N & 552 & & \\
\hline
\end{tabular}

${ }^{\mathrm{a}}$ Not determined.

${ }^{\mathrm{b}}$ Amino acids absorbed from the small intestine.

Table 3. Chemical composition and feeding values of total mixed rations.

\begin{tabular}{lcccc}
\hline & \multicolumn{3}{c}{ Total mixed ration } \\
\cline { 2 - 4 } & $\mathrm{BF} 0$ & $\mathrm{BF} 25$ & $\mathrm{BF} 50$ & $\mathrm{BF} 75$ \\
\hline Dry matter (DM), $\mathrm{g} \mathrm{kg}^{-1}$ & 455 & 456 & 457 & 458 \\
Composition of DM, g kg-1 & & & 945 & 943 \\
Organic matter & 949 & 947 & 151 & 152 \\
Crude protein & 149 & 150 & 40 & 46 \\
Ether extract & 28 & 34 & 472 & 525 \\
Neutral detergent fibre & 368 & 420 & 170 & 106 \\
Starch & 299 & 234 & 11.82 & 11.60 \\
Metabolizable energy, $\mathrm{MJ} \mathrm{kg}^{-1} \mathrm{DM}$ & 12.26 & 12.04 & 95 & 93 \\
$\mathrm{AAT}^{\mathrm{b}}, \mathrm{g} \mathrm{kg}^{-1} \mathrm{DM}$ & 97 & 96 & 95
\end{tabular}

${ }^{a}$ The control diet (BF0) included grass silage and barley grain throughout the experiment. In another three diets (BF25, BF50 and BF75) the concentrate was a mixture (1:1 on DM basis) of barley and barley fibre at stage 1 (up to $450 \mathrm{~kg} \mathrm{LW})$. At stage 2 (450 kg live weight to slaughter) the concentrate in BF25 included barley grain ( $750 \mathrm{~g}$ $\mathrm{kg}^{-1} \mathrm{DM}$ ) and barley fibre (250), in BF50 barley grain (500), barley fibre (500) and in BF75 barley grain (250), barley fibre (750). Hence, at stage 1 only BF0 and BF50 rations were used.

${ }^{\mathrm{b}}$ Amino acids absorbed from the small intestine.

only BF0 and BF50 rations were used, and there were no statistically significant treatment differences in DM, energy or AAT intakes or in LWG (Table 4). However, the feed conversion rate $\left(\mathrm{kg} \mathrm{DM} \mathrm{kg}^{-1}\right.$
LWG) tended to be better with the BF0 than with the BF50 diet (5.87 vs. $6.22, \mathrm{P}=0.10$ ).

At stage 2 (450 kg LW to slaughter), BF replacement had a significant $(\mathrm{P}<0.05)$ quadratic ef- 
Vol. 16 (2007): 232-244

Table 4. Daily live weight gains, dry matter (DM), energy and AAT intakes and feed conversions of bulls up to $450 \mathrm{~kg}$ live weight (stage 1).

\begin{tabular}{|c|c|c|c|c|}
\hline & \multicolumn{2}{|c|}{ Treatment $^{\mathrm{b}}$} & \multirow[t]{2}{*}{$\mathrm{SEM}^{\mathrm{c}}$} & \multirow[t]{2}{*}{ Statistical significance $^{\mathrm{d}}$} \\
\hline & BF0 & BF50 & & \\
\hline$\overline{\mathrm{N}}$ & 8 & 23 & & \\
\hline Duration, $\mathrm{d}$ & 139 & 139 & & \\
\hline Live weight at start, $\mathrm{kg}$ & 260 & 262 & 17.6 & NS \\
\hline Feed intake, $\mathrm{kg} \mathrm{DM} \mathrm{d}^{-1}$ & 8.02 & 8.44 & 0.451 & NS \\
\hline Metabolizable energy (ME) intake, $\mathrm{MJ} \mathrm{d}^{-1}$ & 99.3 & 100.7 & 5.41 & NS \\
\hline AAT intake, $\mathrm{g} \mathrm{d}^{-1}$ & 774 & 804 & 43.1 & NS \\
\hline Live weight gain (LWG), $\mathrm{g} \mathrm{d}^{-1}$ & 1365 & 1358 & 54.0 & NS \\
\hline \multicolumn{5}{|l|}{ Feed conversion } \\
\hline kg DM kg-1 LWG & 5.87 & 6.22 & 0.209 & $\mathrm{P}=0.10$ \\
\hline MJ ME kg-1 LWG & 72.7 & 74.2 & 2.51 & NS \\
\hline AAT $\mathrm{g} \mathrm{kg}^{-1}$ LWG & 567 & 593 & 20.0 & NS \\
\hline
\end{tabular}

${ }^{a}$ Amino acids absorbed from the small intestine. ${ }^{b}$ The control diet (BF0) included grass silage and barley grain. In BF50 the concentrate included barley grain $\left(500 \mathrm{~g} \mathrm{~kg}^{-1} \mathrm{DM}\right)$ and barley fibre (500). ${ }^{\mathrm{c}}$ Standard error of means. ${ }^{\mathrm{d}}$ Statistical significance: NS, not significant, $* \mathrm{p}<0.05, * * \mathrm{p}<0.01, * * * \mathrm{p}<0.001$.

Table 5. Daily live weight gains, dry matter (DM), energy and AAT ${ }^{\mathrm{a}}$ intakes, feed conversions and feed digestion data of bulls at stage 2 (450 kg live weight to slaughter).

\begin{tabular}{|c|c|c|c|c|c|c|c|}
\hline & \multicolumn{4}{|c|}{ Treatment $^{\mathrm{b}}$} & \multirow[t]{2}{*}{$\mathrm{SEM}^{\mathrm{c}}$} & \multicolumn{2}{|c|}{ Statistical significance } \\
\hline & BF0 & $\mathrm{BF} 25$ & $\mathrm{BF} 50$ & BF75 & & 1 & 2 \\
\hline $\mathrm{N}$ & 8 & 8 & 8 & 7 & & & \\
\hline Age at the start, $\mathrm{d}$ & 334 & 336 & 332 & 333 & & & \\
\hline Duration, $\mathrm{d}$ & 174 & 168 & 175 & 190 & & & \\
\hline Feed intake, $\mathrm{kg} \mathrm{DM} \mathrm{d} \mathrm{d}^{-1}$ & 10.45 & 10.70 & 10.98 & 9.83 & 0.398 & NS & * \\
\hline $\begin{array}{l}\text { Metabolizable energy (ME) } \\
\text { intake, } \mathrm{MJ} \mathrm{d}^{-1}\end{array}$ & 127.8 & 128.6 & 129.3 & 113.0 & 4.84 & $*$ & * \\
\hline AAT intake, $\mathrm{g} \mathrm{d}^{-1}$ & 1018 & 1030 & 1044 & 919 & 38.2 & $\mathrm{P}=0.07$ & $*$ \\
\hline Live weight gain (LWG), $\mathrm{g} \mathrm{d}^{-1}$ & 1203 & 1113 & 1130 & 997 & 50.0 & $*$ & NS \\
\hline \multicolumn{8}{|l|}{ Feed conversion } \\
\hline $\mathrm{kg} \mathrm{DM} \mathrm{kg}^{-1} \mathrm{LWG}$ & 8.69 & 9.74 & 9.78 & 9.87 & 0.371 & $*$ & NS \\
\hline MJ ME $\mathrm{kg}^{-1} \mathrm{LWG}$ & 106.3 & 117.0 & 115.2 & 113.9 & 4.45 & NS & $\mathrm{P}=0.09$ \\
\hline AAT $\mathrm{g} \mathrm{kg}^{-1} \mathrm{LWG}$ & 847 & 937 & 930 & 926 & 35.5 & $\mathrm{P}=0.08$ & $\mathrm{P}=0.10$ \\
\hline \multicolumn{8}{|l|}{ Apparent digestibility ${ }^{\mathrm{e}}$} \\
\hline Organic matter & 0.832 & 0.790 & 0.745 & 0.712 & 0.0049 & $* * *$ & NS \\
\hline Crude protein & 0.750 & 0.752 & 0.730 & 0.724 & 0.0074 & $* *$ & NS \\
\hline Neutral detergent fibre & 0.752 & 0.683 & 0.633 & 0.609 & 0.0106 & $* * *$ & $*$ \\
\hline
\end{tabular}

${ }^{\mathrm{a}}$ Amino acids absorbed from small intestine. ${ }^{\mathrm{b}}$ The control diet (BF0) included grass silage and barley grain throughout the experiment. At stage 2 (450 kg live weight to slaughter) the concentrate in BF25 included barley grain ( $\left.750 \mathrm{~g} \mathrm{~kg}^{-1} \mathrm{DM}\right)$ and barley fibre (250), in BF50 barley grain (500), barley fibre (500) and in BF75 barley grain (250), barley fibre (750). ${ }^{c}$ Standard error of means. ${ }^{\mathrm{d}}$ Polynomial contrasts: $(1=$ barley fibre supplementation, linear effect $),(2=$ barley fibre supplementation, quadratic effect $)$. Statistical significance: NS, not significant, $* \mathrm{p}<0.05,{ }^{*} \mathrm{p}<0.01,{ }^{* *} \mathrm{p}<0.001$. ${ }^{\mathrm{e}}$ Diet digestibility was determined in all animals at $512 \pm 30 \mathrm{~kg}$ live weight, on average.

fect on DM, ME and AAT intakes (Table 5). Intakes increased in the BF25 and BF50 diets compared with the BF0 diet, but in the BF75 diets intakes decreased clearly. In energy intake also the linear effect was significant $(\mathrm{P}<0.05)$. The apparent digestibility of OM, CP and NDF decreased linearly with increasing BF supplementation (OM, $\mathrm{P}<0.001$; CP, $\mathrm{P}<0.01$; NDF, $\mathrm{P}<0.001$ ) (Table 
Huuskonen, A. et al. Effects of replacing different proportions of barley grain by barley fibre

5). The apparent digestibility of OM decreased by $17 \%$, CP $3 \%$ and NDF by $19 \%$ when $75 \%$ of barley grain was replaced with $\mathrm{BF}$. With the apparent digestibility of NDF also the quadratic effect of $\mathrm{BF}$ supplementation was significant $(\mathrm{P}<0.05)$. Replacing barley grain with BF decreased LWG linearly $(\mathrm{P}<0.05)$ at stage 2 and resulted in a linear $(\mathrm{P}<0.05)$ reduction in efficiency of conversion of feed to LWG. However, there were no significant differences in ME (MJ ME kg-1 LWG) or AAT ( $\mathrm{g}$ $\mathrm{kg}^{-1} \mathrm{LWG}$ ) conversions (Table 5).

The mean final LW of the bulls was $650 \mathrm{~kg}$. Replacing barley grain with BF led to a linear decrease of daily LWG $(\mathrm{P}<0.05)$ and carcass gain
$(\mathrm{P}<0.01)$ and linear reduction of the feed $(\mathrm{kg} \mathrm{DM}$ per carcass gain, $\mathrm{P}<0.01$ ), energy (MJ $\mathrm{ME} \mathrm{kg}^{-1}$ carcass gain, $\mathrm{P}<0.05)$ and AAT conversion $\left(\mathrm{g} \mathrm{kg}^{-1}\right.$ carcass gain, $\mathrm{P}<0.01)$ on average during the experiment (as measured over the entire experimental period) (Table 6). The treatments affected also slaughter parameters. The dressing proportion and the carcass fat score decreased linearly $(\mathrm{P}<0.05)$ with partial replacement of barley grain with $\mathrm{BF}$. On carcass EUROP conformation, treatment had a significant $(\mathrm{P}<0.05)$ quadratic effect: the $\mathrm{BF} 25$ and BF50 diets were classified highest (Table 6).

Table 6. Daily feed intake and feed conversion (on average during the experiment), live weights, daily gains and slaughter data.

\begin{tabular}{|c|c|c|c|c|c|c|c|}
\hline & \multicolumn{4}{|c|}{ Treatment $^{\mathrm{a}}$} & \multirow[t]{2}{*}{$\mathrm{SEM}^{\mathrm{b}}$} & \multicolumn{2}{|c|}{ Statistical significance ${ }^{c}$} \\
\hline & BF0 & BF25 & BF50 & BF75 & & 1 & 2 \\
\hline Duration, $\mathrm{d}$ & 313 & 307 & 314 & 329 & & & \\
\hline Age at slaughter, d & 508 & 504 & 507 & 523 & & & \\
\hline Dry matter (DM) intake, $\mathrm{kg} \mathrm{d}^{-1}$ & 9.34 & 9.76 & 9.95 & 9.07 & 0.359 & NS & $*$ \\
\hline $\begin{array}{l}\text { Metabolizable energy (ME) in- } \\
\text { take, } \mathrm{MJ} \mathrm{d}^{-1}\end{array}$ & 114.8 & 116.9 & 117.7 & 106.0 & 4.36 & $\mathrm{P}=0.10$ & $*$ \\
\hline $\mathrm{AAT}^{\mathrm{d}}$ intake, $\mathrm{g} \mathrm{d}^{-1}$ & 907 & 935 & 946 & 856 & 34.4 & NS & $*$ \\
\hline Initial live weight, $\mathrm{kg}$ & 260 & 260 & 261 & 265 & 18.3 & NS & NS \\
\hline Final live weight, kg & 659 & 644 & 659 & 637 & 15.3 & NS & NS \\
\hline Live weight gain, $\mathrm{g} \mathrm{d}^{-1}$ & 1280 & 1252 & 1271 & 1127 & 50.4 & $*$ & NS \\
\hline Carcass gain, $\mathrm{g} \mathrm{d}^{-1}$ & 721 & 720 & 690 & 612 & 25.3 & $* *$ & NS \\
\hline \multicolumn{8}{|l|}{ Feed conversion } \\
\hline $\mathrm{kg} \mathrm{DM} \mathrm{kg}^{-1}$ carcass gain & 12.96 & 13.55 & 14.50 & 14.86 & 0.416 & $* *$ & NS \\
\hline MJ ME kg-1 carcass gain & 159.3 & 162.3 & 171.6 & 173.5 & 4.93 & $*$ & NS \\
\hline AAT $\mathrm{g} \mathrm{kg}^{-1}$ carcass gain & 1259 & 1299 & 1380 & 1401 & 39.6 & $* *$ & NS \\
\hline \multicolumn{8}{|l|}{ Slaughter data } \\
\hline Carcass weight, kg & 350 & 346 & 342 & 329 & 7.6 & $*$ & NS \\
\hline Dressing proportion, $\mathrm{g} \mathrm{kg}^{-1}$ & 532 & 538 & 519 & 518 & 6.3 & $*$ & NS \\
\hline EUROP conformation ${ }^{\mathrm{e}}$ & 4.0 & 4.5 & 4.4 & 3.3 & 0.34 & NS & $*$ \\
\hline EUROP fat classification $^{\mathrm{f}}$ & 3.3 & 3.0 & 3.0 & 2.7 & 0.16 & $*$ & NS \\
\hline
\end{tabular}

${ }^{a}$ The control diet (BF0) included grass silage and barley grain throughout the experiment. In another three diets (BF25, BF50 and BF75) the concentrate was a mixture (1:1 on DM basis) of barley and barley fibre at stage 1 (up to $450 \mathrm{~kg} \mathrm{LW}$ ). At stage 2 (450 kg live weight to slaughter) the concentrate in BF25 included barley grain $\left(750 \mathrm{~g} \mathrm{~kg}^{-1} \mathrm{DM}\right)$ and barley fibre (250), in BF50 barley grain (500), barley fibre (500) and in BF75 barley grain (250), barley fibre (750). Hence, at stage 1 only BF0 and BF50 rations were used. ${ }^{\mathrm{b}}$ Standard error of means. ${ }^{\mathrm{c}}$ Polynomial contrasts: $(1$ = barley fibre supplementation, linear effect $),(2=$ barley fibre supplementation, quadratic effect $)$. Statistical significance: NS, not significant, ${ }^{*} \mathrm{p}<0.05,{ }^{* *} \mathrm{p}<0.01,{ }^{* * *} \mathrm{p}<0.001 .{ }^{\mathrm{d}}$ Amino acids absorbed from the small intestine.

${ }^{\mathrm{e}}$ Conformation: $(1=$ poorest, $15=$ excellent $) .{ }^{\mathrm{f}}$ Fat cover: $(1=$ leanest, $5=$ fattest $)$. 
Vol. 16 (2007): 232-244

\section{Discussion}

The objective of this trial was to study the effects of partial replacement of barley grain with $\mathrm{BF}$ on animal performance, carcass traits and diet digestibility of growing dairy bulls. The trial was separated so that in stage 1 (from the initiation of the study to $450 \mathrm{~kg} \mathrm{LW}$ ) there were only two treatments (control and BF50) and stage 2 (from $450 \mathrm{~kg} \mathrm{LW}$ to slaughter) included all four treatment groups (control, BF25, $\mathrm{BF} 50$ and BF75). There were only two treatments in stage 2 because, according to preliminary findings, the bulls performed well when $50 \%$ of the barley grain concentrates was replaced with BF in the early part of the growing period (Root and Huhtanen 1998: LW 205 to $350 \mathrm{~kg}$, Huuskonen unpublished data: LW 280 to $500 \mathrm{~kg}$ ).

Some by-product feeds can be very variable in nutrient composition, but the chemical and nutritional compositions of commercial BF is fairly constant (Asko Rantanen, personal communication, Altia Ltd, May 7, 2007). The nutrient composition of the BF used in the present experiment was quite similar to, for example, that reported by Mäntysaari et al. (2007).

In the present study there were no treatment differences in LWG $\left(1359 \pm 139.9 \mathrm{~g} \mathrm{~d}^{-1}\right.$, on average) at stage 1 , and no differences in DM, energy or AAT intakes. These results are similar to those of Root and Huhtanen (1998) who reported no significant differences when replacing barley grain partly with $\mathrm{BF}$ up to $350 \mathrm{~kg} \mathrm{LW}$ with separate feeding. In the present trial, feed efficiency $\left(\mathrm{kg} \mathrm{DM} \mathrm{kg}^{-1}\right.$ LWG) tended to be better with the BF0 than with the BF50 diet at stage 1. Root and Huhtanen (1998) reported no difference in feed conversion up to 350 $\mathrm{kg} \mathrm{LW}$, but from $350 \mathrm{~kg} \mathrm{LW}$ to slaughter replacing barley grain by BF reduced the feed conversion. These data indicate that during the early part of the growing period (LW 200 to $400 \mathrm{~kg}$ ), 50\% of barley starch can be replaced with BF without affecting growth or feed efficiency factors.

At stage 2 and also throughout the entire period, replacing barley grain with BF decreased LWG linearly in the present study. Impaired gain of BF75 bulls was a consequence of decreased DM and energy intake, which was possibly partly caused by decreased OM digestibility (OMD). Replacing barley grain with $\mathrm{BF}$ in the diet affected the OMD similarly as observed by Huhtanen (1992) in bulls and by Huhtanen et al. (1988) in dairy cows. Barley fibre contains much more NDF and less starch than barley grain, and the difference in OMD can be attributed to a lower digestibility of cell wall components of BF than of those of barley starch. Since NDF digestibility decreased with increasing BF proportion in the present study, the difference in NDF digestibilities reflected the increased proportion of BF. The reduction in NDF digestibility was partly a consequence of decreasing proportion of silage's NDF in the total diet when the BF proportion increased, because silage fibre is more digestible than the fibre fraction of barley (Van Soest 1994, MTT 2006). In addition, this difference between fibre digestibilities is possibly higher in northern latitudes, because grasses grown there exhibited a higher digestibility at the same stage of maturity than those grown at latitudes closer to the equator (Deinum et al. 1968). This is due to temperature and light intensity which influence the lignification of the cell wall, which affects the relationship between fibre and digestibility (Deinum et al. 1968, Van Soest 1994).

It is also possible that the decreasing NDF digestibility with increasing BF proportion was partly due to the fat content of BF which was higher than that of barley grain ( 65 vs. $22 \mathrm{~g} \mathrm{~kg}^{-1} \mathrm{DM}$ ). Fatbased concentrates are inferior to starch or fibrebased concentrates as supplements to grass silage which is attributed to a lower organic matter digestibility for the former (e.g. Moloney 1996). Fat supplementation, even at quite low levels (40-50 $\mathrm{g} \mathrm{kg}^{-1} \mathrm{DM}$ ), has been shown to depress fibre digestion (e.g. Ikwuegbu and Sutton 1982, Murphy et al. 1987). Therefore, extensive use of fat in ruminant diets has been limited because of the inhibitory effects of fatty acids on ruminal microbial metabolism (Palmquist and Jenkins 1980, Merchen et al. 1997). Apparent total tract digestibilities of fibre components decrease by supplementation of fats, particularly when large amounts of highly unsaturated vegetable oils (Ward et al. 1957), oilseeds (Drackley et al. 1985) or unsaturated animal fats, 


\section{AGRICULTURAL AND FOOD SCIENCE}

Huuskonen, A. et al. Effects of replacing different proportions of barley grain by barley fibre

such as yellow grease (Jenkins and Jenny 1989), are fed. According to Doreau and Chillard (1997), dietary supplementation with fat, especially polyunsaturated fats, of more than $50 \mathrm{~g}$ added fat $\mathrm{kg}^{-1}$ concentrates, has an increasingly adverse effect on ruminal digestion of fibre. However, disruptions in ruminal fibre digestion with added fat have been observed mostly with sheep or steers fed at or slightly above maintenance intakes (Ikwuegbu and Sutton 1982, Jenkins and Palmquist 1984, Jenkins and Fotouhi 1990). Some recent studies (e.g. Christensen et al. 1996) show that ruminal digestion of structural carbohydrates is not affected by supplementation of fat in dairy cows at higher intakes. Dry matter intake (DMI) has a great effect on ruminal digestion of OM and passage of microbial protein to the duodenum (Clark et al. 1992) and may thus override many of the negative effects of fat supplementation (Merchen et al. 1997). The DMI of bulls is clearly lower than that of high-producing dairy cows. It is therefore possible that the fibre digestion may have been affected in the present trial when the fat content of TMR increased from 28 to $46 \mathrm{~g}$ $\mathrm{kg}^{-1} \mathrm{DM}$ with increasing BF proportion. However, the mechanisms of digestion are complicated and besides intake, there are many other factors that can influence ruminal responses to supplemental fats, including fatty acid profile and chemical form of the fat (Pantoja et al. 1994, 1995), ruminal availability of the fat (Ohajuruka et al. 1991), Ca content of the diet (Bock et al. 1991, Doreau et al. 1993), as well as source, content and particle size of dietary fibre (Ben Salem et al. 1993, Hussein et al. 1995, Tackett et al. 1996).

The reduced gain and lower DM and energy intake of the BF75 diet were not caused only by the reduction in OMD since replacing barley grain with BF had a curvilinear effect on DM, energy and protein intakes at stage 2 and during the entire period. Intakes increased with the BF25 and BF50 diets compared with the control diet, but decreased with BF75 compared with the control diet. In the present study, the increased DMI with the BF25 and BF50 diets to the level of ME supply with the control diet suggested an energetic regulation of feed intake. When cattle are fed high-energy rations that are palatable, low in fill and readily digested, intake is regulated to meet the energy demands of the animal, unless the diet is fermented too rapidly and digestive disorders occur (Montgomery and Baumgardt 1965, Baile and Forbes 1974). It is suggested that, when the energy content of the diet decreased (usually with increasing NDF content), the animal can increase its DMI until rumen fill (Mertens 1994, Forbes 1995). In the present study, the silage used was of good nutritional quality and the concentrates were quite highly digestible. Therefore the bulls could increase DMI when the energy content of the rations decreased with BF 25 and BF50 diets compared with the control. In addition, replacing starch with fibrous concentrate may change rumen fermentation by increasing rumen $\mathrm{pH}$, resulting in more efficient cellulolysis in the rumen, especially with high concentrate proportions (Huhtanen et al. 1988), which may partly explain the increased DMI observed with the BF25 and BF50 diets compared with the control. However, DMI decreased when $75 \%$ of the barley grain concentrates was replaced with BF, so on the BF75 diet the bulls could not compensate the lower energy content of TMR by increasing DMI. This was probably due to the palatability of BF which was not very good. Subjective observations during the experiment support this conclusion, and also Huhtanen et al. (1989) reported that the palatability of BF was not good in the study with growing bulls. On the other hand, Root and Huhtanen (1998) reported a good palatability of $\mathrm{BF}$ in their experiment, but in that trial the highest $\mathrm{BF}$ intake was $3.3 \mathrm{~kg} \mathrm{DM} \mathrm{d}^{-1}$, being at the same level as in the BF50 diet in the present study which was approximately $30 \%$ less than the maximum $\mathrm{BF}$ intakes in the BF75 diet.

Root and Huhtanen (1998) and Huhtanen et al. (1989) did not report any response of DMI to replacing barley grain with $\mathrm{BF}$ in dairy bulls with separate feeding. In these studies by Huhtanen et al. (1989) and Root and Huhtanen (1998), the average concentrate proportions and concentrate intakes were lower (420 $\mathrm{g} \mathrm{kg}^{-1} \mathrm{DM} ; 2.89 \mathrm{~kg} \mathrm{DM} \mathrm{d}^{-1}$ and $390 \mathrm{~g} \mathrm{~kg}^{-1} \mathrm{DM} ; 3.01 \mathrm{~kg} \mathrm{DM} \mathrm{d}^{-1}$, respectively) than in the present study $\left(540 \mathrm{~g} \mathrm{~kg}^{-1} \mathrm{DM} ; 5.20 \mathrm{~kg} \mathrm{DM}\right.$ $\mathrm{d}^{-1}$ ). Different concentrate proportions, concentrate intakes and feeding methods (separate vs. TMR) probably explain the differences between experi- 
Vol. 16 (2007): 232-244

ments in feed intake. In the present study linearly depressed feed and energy conversion during the entire period when barley grain was replaced by barley fibre was due to effects on DM and energy intakes and gain. These results are similar to the previous results by Root and Huhtanen (1998) who reported reducing feed conversion when replacing barley grain partly with BF $350 \mathrm{~kg} \mathrm{LW}$ to slaughter. These data indicate that, during the final part of the growing period (LW 400 to slaughter), 50\% of barley starch can be replaced with BF without affecting growth, but feed efficiency factors may decrease when barley starch is replaced with BF. In the course of our trial, the calculated supply of energy was $12 \%$ higher than in the Finnish feeding recommendations (MTT 2006) for present growth on average. This is consistent with our earlier findings with dairy bulls fed TMR (Huuskonen et al. 2007) and indicates that the current Finnish energy recommendations are probably too low for dairy bulls of a LW of more than $250 \mathrm{~kg}$.

The dressing proportion decreased with increasing $\mathrm{BF}$ proportion in the present study. Also Root and Huhtanen (1998) reported that the dressing proportion tended to be lower for BF than for barley grain diets, assuming that it may be due to differences in rumen fill. Root and Huhtanen (1998) supposed that compared to bulls fed BF, bulls fed barley grain may have stopped eating with smaller rumen fill for metabolic reasons, mainly feedback mechanism of increased amount of rumen fermentation end products, leading to lighter weight of rumen contents with barley grain. However, the effect of fibrous concentrate on the dressing proportion is not very clear. For example, Huhtanen et al. (1989) and Jaakkola and Huhtanen (1990) reported no effect on dressing proportion, when barley grain was replaced with fibrous concentrate (BF or sugar beet pulp). With increasing level of $\mathrm{BF}$ in the diet, carcass fat classification decreased by $22 \%$ in the present experiment. According to literature, reducing energy intake usually decreases carcass fat content (e.g. Harrison et al. 1978, Fishell et al. 1985), which could explain the lower fat classification on the BF75 diet. On the other hand, measures of fatness increase also with increasing carcass weight (Keane and Allen 1998) and in our trial carcass weight decreased with increasing level of BF, which probably also explained the differences in fatness. For cattle finished on grass silage and concentrates, Steen and Kilpatrick (2000) concluded that reducing slaughter weights is likely to be a more effective strategy to control carcass fat content than reducing energy intake either by diet restriction or concentrate proportion. The explanation for the quadratic effect on carcass conformation in the present experiment is not clear. Probably higher energy intake partly explains the increased conformation score with the BF25 and BF50 diets. Caplis et al. (2005) reported that carcass conformation of finishing steers increased with increasing concentrate level and energy intake. In previous studies with barley by-products (Huhtanen et al. 1989, Root and Huhtanen 1998), the carcass conformation or fat score of bulls was not significantly affected by the BF replacement. However, in the studies by Huhtanen et al. (1989) and Root and Huhtanen (1998), the carcass weights were considerably lower (224 kg and $260 \mathrm{~kg}$, respectively) than in the present study.

In conclusion, barley fibre was a suitable energy supplement with good-quality silage for growing dairy bulls. The results indicate that $50 \%$ of barley starch can be replaced with BF without affecting growth, but feed efficiency factors may decrease when barley starch is replaced with BF. At 75\% replacement, DMI decreased, resulting in a lower $\mathrm{ME}$ intake and reduced level of performance. The rationality of the use of BF in the future will depend on the price in relation to other concentrates.

Acknowledgements. This study was partially funded by the Employment and Economic Development Centre for Northern Ostrobothnia, Altia Ltd and A-Farmers Ltd. The authors would like to thank Mr. Lauri Jauhiainen for advice on statistical analyses. The authors wish to express their gratitude also to Mr. Matti Huumonen and his personnell for technical assistance and excellent care of the experimental animals. The personnell at Animal Production Research in Jokioinen is also thanked for the laboratory analyses. Dr Mikko Tuori is acknowledged for his valuable comments and criticism on the current manuscript. 


\section{AGRICULTURAL AND FOOD SCIENCE}

Huuskonen, A. et al. Effects of replacing different proportions of barley grain by barley fibre

\section{References}

Ahvenjärvi, S., Vanhatalo, A., Huhtanen, P. \& Varvikko, T. 2000. Determination of reticulo-rumen and whole stomach digestion in lactating cows by omasal canal and duodenal sampling. British Journal of Nutrition 83: 67-77.

AOAC 1990. Official methods of analysis. 15th edition. Associations of Official Analytical Chemists, Arlington, VA. 1298 p.

Baile, C.A. \& Forbes, J.M. 1974. Control of feed intake and regulation of energy balance in ruminants. Physiological Reviews 54: 160-214.

Ben Salem, H., Krzeminski, R., Ferlay, A. \& Doreau, M. 1993. Effects of lipid supply on in vivo digestion in cows: comparison of hay and corn silage diets. Canadian Journal of Animal Science 73: 547-557.

Bock, B.J., Harmon, D.L., Brandt, R.T. Jr. \& Schneider, J.E. 1991. Fat source and calcium level effects on finishing steer performance, digestion, and metabolism. Journal of Animal Science 69: 2211-2224.

Caplis, J., Keane, M.G., Moloney, A.P. \& O'Mara, F.B. 2005. Effects of supplementary concentrate level with grass silage, and separate or total mixed ration feeding, on performance and carcass traits of finishing steers. Irish Journal of Agricultural and Food Research 44: 27-43.

Christensen, R.A., Overton, T.R., Clark, J.H., Drackley, J.K., Nelson, D.R. \& Blum, S.A. 1996. Effects of dietary fat with or without nicotinic acid on nutrient flow to the duodenum of dairy cows. Journal of Dairy Science 79: $1410-1424$.

Clark, J.H., Klusmeyer, T.H. \& Cameron, M.R. 1992. Microbial protein synthesis and flow of nitrogen fractions to the duodenum of dairy cows. Journal of Dairy Science 75: 2304-2323.

Commission of the European Communities 1982. Commission of the European Communities (Beef Carcass Classification) Regulations. Council Regulations 1358/80, 1208/81, 1202/82. Commission Regulations 2938/81, 563/82, 1557/82, Brussels.

Deinum, B., Van Es, A.J.H. \& Van Soest, P.J. 1968. Climate, nitrogen and grass. II. The influence of light intensity, temperature and nitrogen on in vivo digestibility of grass and prediction of these effects from some chemical procedures. Netherlands Journal of Agricultural Science 16: 217-223.

Doreau, M. \& Chilliard, Y. 1997. Digestion and metabolism of dietary fat in animals. British Journal of Nutrition 78: Supplement 1: S15-S35.

Doreau, M., Ferlay, A. \& Elmeddah, Y. 1993. Organic matter and nitrogen digestion by dairy cows fed calcium salts of rapeseed oil fatty acids or rapeseed oil. Journal of Animal Science 71: 499-504.

Drackley, J.K., Clark, A.K. \& Sahlu, T. 1985. Ration digestibilities and ruminal characteristics in steers fed sunflower seeds with additional calcium. Journal of Dairy Science 68: 356-367.

Fishell, V.K., Aberle, E.D., Judge, M.D. \& Perry, T.W. 1985. Palatability and muscle properties of beef as influenced by preslaughter growth rate. Journal of Animal Science 61: 151-157.

Forbes, J.M. 1995. Voluntary Food Intake and Diet Se- lection in Farm Animals. CAB International, Wollingford, UK. 333 p.

Harrison, A.R., Smith, M.E., Allen, D.M., Hunt, M.C., Kastner, C.L. \& Kropf, D.H. 1978. Nutritional regime effects on quality and yield characteristics of beef. Journal of Animal Science 47: 383-388.

Huhtanen, P. 1992. The effects of barley vs. barley fibre with or without distiller's solubles on site and extent of nutrient digestion in cattle fed grass-silage-based diet. Animal Feed Science and Tehcnology 36: 319-337.

Huhtanen, P., Ala-Seppälä, H., Näsi, M. 1988. Response of silage intake and milk production to replacement of barley fibre derived from integrated starch-ethanol process. Journal of Agricultural Science in Finland 60: 711-721.

Huhtanen, P., Näsi, M. \& Khalili, H. 1989. By-products from integrated starch-ethanol production from barley in the diets of growing cattle. Journal of Agricultural Science in Finland 61: 451-462.

Hussein, H.S., Merchen, N.R. \& Fahey, G.C. Jr. 1995. Effects of forage level and canola seed supplementation on site and extent of digestion of organic matter, carbohydrates, and energy by steers. Journal of Animal Science 73: 2458-2468.

Huuskonen, A., Khalili, H. \& Joki-Tokola, E. 2007. Effects of three different concentrate proportions and rapeseed meal supplement to grass silage on animal performance of dairy-breed bulls with TMR feeding. Livestock Science 110: 154-165.

Ikwuegbu, O.A. \& Sutton, J.D. 1982. The effect of varying the amount of linseed oil supplementation on rumen metabolism in sheep. British Journal of Nutrition 48: 365-375.

Jaakkola, S. \& Huhtanen, P. 1990. Response to cellulase treatment of silage and replacement of barley by unmolassed sugar beet pulp in the diets of growing cattle. Acta Agriculturae Scandinavica 40: 415-426.

Jenkins, T.C. \& Fotouhi, N. 1990. Effect of lecithin and corn oil on site of digestion, ruminal fermentation and microbial protein synthesis in sheep. Journal of Animal Science 68: 460-466.

Jenkins, T.C. \& Jenny, B.F. 1989. Effect of hydrogenated fat on feed intake, nutrient digestion, and lactation performance of dairy cows. Journal of Dairy Science 72: 2316-2324.

Jenkins, T.C. \& Palmquist, D.L. 1984. Effect of fatty acids or calcium soaps on rumen and total nutrient digestibility of dairy rations. Journal of Dairy Science 67: 978-986.

Keane, M.G. \& Allen, P. 1998. Effects of production system intensity on performance, carcass composition and meat quality of beef cattle. Livestock Production Science 56: 203-214.

MAFF 1981. Animal Science 1979. ADAS Reference Book 254. Ministry of Agriculture, Fisheries and Food. Her Majesty's Stationery Office, London. $103 p$.

MAFF 1984. Energy allowances and feeding systems for ruminants. ADAS Reference Book 433. Ministry of Agriculture, Fisheries and Food. Her Majesty's Stationary Office, London. $85 \mathrm{p}$.

Mäntysaari, P., Khalili, H., Sariola, J. \& Rantanen, A. 2007. Use of barley fibre and wet distillers' solubles as feedstuffs for Ayrshire dairy cows. Animal Feed Science and Technology 135: 52-65.

McCleary, B.V., Solah, V. \& Gibson, T.S. 1994. Quantitative 


\title{
AGRICULTURAL AND FOOD SCIENCE
}

\author{
Vol. 16 (2007): 232-244
}

measurement of total starch in cereal flours and products. Journal of Cereal Science 20: 51-58.

Merchen, N.R., Elizalde, J.C. \& Drackley, J.K. 1997. Current perspective on assessing site of digestion in ruminants. Journal of Animal Science 75: 2223-2234.

Mertens, D.R. 1994. Regulation of forage intake. In: Fahey, Jr, G.C., Collins, M., Mertens, D.R. \& Moser, L.E. (ed.). Forage Quality, Evaluation and Utilization. Madison, WI, USA: American Society of Agronomy, Crop Science Society of America, Soil Science Society of America. p. 450-493.

Moisio, T. \& Heikonen, M. 1989. A titration method for silage assessment. Animal Feed Science and Technology 22: 341-353.

Moloney, A.P. 1996. Digestion and growth in steers fed grass silage and starch, fibre or fat-based concentrates. Irish Journal of Agricultural and Food Research 35: 65 (Abstract).

Montgomery, J.J. \& Baumgardt, B.R. 1965. Regulation of food intake in ruminants. II. Rations varying in energy concentrations. Journal of Dairy Science 48: 16231628.

MTT 2006. Rehutaulukot ja ruokintasuositukset (Feed tables and feeding recommendations). Agrifood Research Finland, Jokioinen. Published 14.2.2006, cited 13.1.2007. Available on the internet: www.agronet.fi/rehutaulukot/. URN:NBN:fi-fe20041449.

Murphy, M., Udén, P., Palmquist, D.L. \& Wiktorsson, H. 1987. Rumen and total tract digestibilities in lactating cows fed diets containing full-fat rapeseed. Journal of Dairy Science 70: 1572-1582.

Näsi, M. 1988. Evaluating barley feed fractions from integrated ethanol-starch production in diets of ruminants. Journal of Agricultural Science in Finland 60: 701-709.

Nousiainen, J., Rinne, M., Hellämäki, M. \& Huhtanen, P. 2003. Prediction of the digestibility of the primary growth of grass silages harvested at different stages of maturity from chemical composition and pepsin-cellulase solubility. Animal Feed Science and Technology 103: 97-111.

Oharujuka, O.A., Wu, Z. \& Palmquist, D.L. 1991. Ruminal metabolism, fiber, and protein digestion by lactating cows fed calcium soap or animal-vegetable fat. Journal of Dairy Science 74: 2601-2609.

Palmquist, D.L. \& Jenkins, T.C. 1980. Fat in lactation rations: Review. Journal of Dairy Science 63: 1-14.

Pantoja, J., Firkins, J.L., Eastridge, M.L. \& Hull, B.L. 1994. Effects of fat saturation and source of fiber on site of nutrient digestion and milk production by lactating dairy cows. Journal of Dairy Science 77: 2341-2356.

Pantoja, J., Firkins, J.L., Eastridge, M.L. \& Hull, B.L. 1995. Site of digestion and milk production by cows fed fats differing in saturation, esterification, and chain length. Journal of Dairy Science 78: 2247-2258.

Root, T. \& Huhtanen, P. 1998. Barley fibre and wet distillers' solubles in the diet of growing cattle. Agricultural and Food Science in Finland 7: 357-366.

SAS 1999. SAS/STAT user's guide. Version 8, Cary, NC. SAS Institute Inc. 3809 p.

Schiemann, R., Nehring, K., Hoffmann, L., Jentsch, W. \& Chudy, A. 1972. Energetische Futterbewertung und Energienormen. VEB Deutcher Landwirtschafsverlag Berlin, Germany. 344 p.

Steen, R.W.J. \& Kilpatrick, D.J. 2000. The effects of the ratio of grass silage to concentrates in the diet and restricted dry matter intake on the performance and carcass composition of beef cattle. Livestock Production Science 62: 181-192.

Tackett, V.L., Bertrand, J.A., Jenkins, T.C., Pardue, F.E. \& Grimes, L.W. 1996. Interaction of dietary fat and acid detergent fiber diets of lactating dairy cows. Journal of Dairy Science 79: 270-275.

Van Keulen, J. \& Young, B.A. 1977. Evaluation of acid-insoluble ash as a marker in ruminant digestibility studies. Journal of Animal Science 44: 282-287.

Van Soest, P.J. 1994. Nutritional ecology of the ruminant. Second Edition. Comstock Publishing Associates, Cornell University Press, Ithaca and London. $476 \mathrm{p}$.

Ward, J.K., Tefft, C.W., Sirny, R.J., Edwards, H.N. \& Tillman, A.D. 1957. Further studies concerning the effect of alfalfa ash upon the utilization of low-quality roughages by ruminant animals. Journal of Animal Science 16: 633-641. 
Huuskonen, A. et al. Effects of replacing different proportions of barley grain by barley fibre

\title{
SELOSTUS
}

\section{Ohrarehu maitorotuisten sonnien seosrehuruokinnassa}

\author{
Arto Huuskonen, Hannele Khalili ja Erkki Joki-Tokola
}

MTT Kotieläintuotannon tutkimus

\begin{abstract}
Tutkimuksen tarkoituksena oli kartoittaa integroidun tärkkelys-etanoliteollisuuden sivutuotteena syntyvän ohrarehun käyttöä kasvavien lihanautojen seosrehuruokinnassa. Kokeessa oli mukana 32 maitorotuista sonnia, jotka painoivat kokeen alussa $261 \mathrm{~kg}$ ja lopussa $650 \mathrm{~kg}$. Erilaisia koeruokintoja oli neljä. Kontrolliruokinta sisälsi ainoastaan nurmisäilörehua (46 \%) ja ohraa (54\% kuiva-aineesta) koko kokeen ajan. Kolmessa muussa ruokintaryhmässä väkirehu sisälsi puolet ohraa ja puolet ohrarehua siihen saakka, kunnes sonnit saavuttivat $450 \mathrm{~kg}: n$ elopainon. Tästä eteenpäin väkirehussa oli ohraa 75, 50 tai 25 prosenttia, ja vastaavasti ohrarehua 25, 50 tai 75 prosenttia kuiva-aineesta. Kaikki eläimet saivat vapaasti seosrehua, ja väkirehuprosentti oli kaikilla ruokinnoilla sama (54) koko kokeen ajan.
\end{abstract}

Kun ohraa korvattiin ohrarehulla, orgaanisen aineen ja kuidun näennäinen in vivo -sulavuus heikkeni. Ohraruokintaan verrattuna orgaanisen aineen sulavuus heikkeni 17 prosenttia, kun ohrasta 75 prosenttia oli korvattu ohrarehulla. Ohran osittainen korvaaminen vaikutti myös rehun syöntiin. Syönti lisääntyi, kun ohrasta 25 tai 50 prosenttia oli korvattu ohrarehulla. Sen sijaan 75 prosentin korvaaminen vähensi rehun syöntiä. Ohran osittainen korvaaminen ohrarehulla heikensi hieman kasvutuloksia. Samoin teurasprosentti ja ruhojen rasvaisuus pienenivät. Tulosten perusteella enintään puolet kasvavan sonnin väkirehuannoksesta on mahdollista korvata ohrarehulla. Ohrarehun käytön ratkaisee kuitenkin viime kädessä sen hinta suhteessa muihin väkirehuihin. 